\title{
Harvesting The Wind
}

\section{Wind energy may be a profitable companion crop.}

\section{By Kindra Gordon}

Looking for another crop to harvest? Consider the wind.

"Wind turbines are compatible with raising crops, forages and livestock. They take less than $2 \%$ of the land out of production, so it's not replacing what's there. It is an additional source of revenue," says Lisa Daniels, director of Windustry, a Minnesota-based organization devoted to educating landowners about wind energy.

With wind energy potential pegged at 10,777 billion kilowatts $(\mathrm{kWh})$ annually - three times the amount of power the U.S. now uses - many 200 -foot tall wind turbines have already been erected by the dozens on ag lands across the country. As the nation's fastest-growing power source, wind energy's appeal is bolstered by its environmentally-friendly attributes and the potential to reduce American reliance on foreign energy.

North and South Dakota, Minnesota, Iowa, Wyoming, Nebraska, Kansas and Oklahoma are the top states with wind energy development potential, according to the American Wind Energy Association. And, as Daniels points out, the turbines are compatible with about any land use. The 2002 Farm Bill even allows wind turbines to be erected on idle lands enrolled in the Conservation Reserve Program.

Last year, South Dakotan Jason Runestad and his parents John and Sharon had eight wind turbines erected on pasture land used for their commercial cow-calf operation. The turbines are part of a 27-turbine wind farm located near Highmore, SD and operated by a Florida-based energy company. The Runestad's and other landowners involved with the project, lease the land with the wind towers on it to the power company, and Runestad says once the towers are constructed there is little interference with their livestock grazing operation. "It's been a good deal and an extra source of income," he says.

\section{Income Opportunities}

Although much of the future growth in the wind industry is expected to come from large wind power plants run by corporations, small clusters of turbines operated by local landowners and small businesses are also viable. In these scenarios, there are two potential revenue streams for landowners.

The most popular is through leasing land to wind developers, which can generate $\$ 2,000$ to $\$ 5,000$ of income for the landowner per machine per year, says Daniels, depending on size of the machine and contract negotiations. "There is no real expense on the landowners side, however there is limited reward as far as income potential," she points out.

As a second option, local entities can produce the wind power themselves and sell it to utility companies. Daniels says, "As people become more familiar with wind energy, I think we'll see more elements of local ownership of these projects - whether it be a school district, a local utility company, or a group of producers."

Income potential with these larger scale projects could produce up to six-digit returns after expenses are paid off, according to some estimates.

Most importantly, the demand for wind energy appears to be growing with several U.S. utilities already buying wind power or owning turbines outright. That's expected to continue, especially as federal initiatives aim to have more than 10,000 megawatts (MW) of wind capacity being used in the U.S. by 2010 .

Once developed, wind energy portends to be an economic boost to the ag economy. Daniels reports that each $100 \mathrm{MW}$ of wind development in southwest Minnesota has generated about $\$ 1$ million annually in property tax revenue and about $\$ 250,000$ per year in direct lease payments to landowners.

For more information visit www.windustry.com. 


\section{Resource Roundup}

\section{California Ranchers Named Top Stewards}

Elaine and George Work, owners of Work Family Ranch of San Miguel, Calif., were named the national winners of the 2004 Environmental Stewardship Award Program (ESAP) by the National Cattlemen's Beef Association (NCBA) during a reception Jan. 29 at the 2004 Cattle Industry Annual Convention and Trade Show in Phoenix, Ariz.

Sponsored by Dow AgroSciences, the Environmental Stewardship Award Program recognizes cattle producers whose stewardship practices are inventive, cost-effective and contribute to environmental conservation. The recipients of this top U.S. beef industry environmental award are selected by a committee of representatives from university faculty, federal and state government agencies, and conservation and environmental organizations.

The Work Family Ranch is a combination cowcalf and stocker operation. It is family-owned and well on its way to being operated by the fifth generation. The ranch features guided hunts, a Farmstay program, public trail rides, and a girls' horse camp.

The ranch, which was originally homesteaded in the late $1890 \mathrm{~s}$, is located in Monterey and San Luis Obispo counties. It consists of 12,000 owned acres, with 9,000 acres for grazing on native and non-native perennial grasses, 1,000 acres for dryland farming, 1,000 acres enrolled in the Conservation Reserve Program (CRP) and 1,000 acres rotated between pasture and crops. The ranch is considered a year-round grazing operation with no supplementation to their 200 head of mother cows and 200 head of stockers.

Other regional winners recognized by NCBA's annual environmental stewardship program included Carlton 2 × 4 Ranch, Arcadia, FL; M\&M Cattle Co., Carthage, MO; Canyon View Farms, Geary, $\mathrm{OK}$; Frasier Farms, Limon, CO; and Barenthsen Red Angus Ranch, Powers Lake, ND.

\section{GPS Offers Grazing Insight}

Most long-time ranchers think they know their cattle pretty well - right down to their favorite grazing spots. But the newest technology - Global
Positioning Systems (GPS) - is offering helpful insight into the world of livestock grazing. Texas A\&M Extension range specialist Robert Lyons is using this technology on three ranches to help determine where animals are, and are not, grazing.

On each of the three ranches, four to six animals among a herd of about 50 were collared with GPS collars and their location points were plotted with GPS every five minutes, 24 hours a day during the study periods. Results revealed that animals often avoided particular areas within the pasture - sometimes the areas were too far from water, too heavily covered with brush, too steeply sloped or too rocky.

"Grazing distribution was uneven in all of the ranches studied," Lyons reports. While many would expect this to be so, with the GPS data points of the animals plotted on a map, landowners can see exactly which areas are being used and those being avoided.

Lyons says that is powerful information. "With that knowledge, landowners can eliminate some of these problem areas with management. In some situations they can adapt to the challenge and perhaps save those areas for wildlife or recreation."

Lyons reports that individual GPS collars cost about $\$ 4,500$, but he says they are a worthwhile research tool that will provide valuable grazing management applications in the years to come.

\section{Sharing Ideas}

For producers with grazing management questions, North Dakota and Nebraska have both taken a unique approach to help share ideas. Grazing coalitions in each state have set up a mentoring network to help offer information, ideas, and insight to interested producers and agency personnel.

The mentoring group consists of experienced grazing land managers across the state who have agreed to provide guidance and counsel based on knowledge and experience they've gained in their business and interaction with other ranchers across the country. The coalitions in each respective state have developed a brochure with a list and contact information for the mentors who can be contacted, as well as noted those individuals particular area of 
expertise. To learn more, contact North Dakota's Todd Hagel at todd.hagel@nd.usda.gov or Nebraska's Roger Chesley at rchesley@gpcom.net.

\section{Order Your Proceedings From GLCI}

The latest research, technologies and management ideas for grazing programs were presented at the Second National Conference on Grazing Lands held in Nashville, Dec. 7-10, 2003. Sponsored by the Grazing Lands Conservation Initiative (GLCI) and its industry partners including SRM, the event included 175 speakers on topics including wildlife livestock interactions, grazing and endangered species, grazing management on small acreages and much more. If you were unable to attend the Second National Grazing Conference, proceedings will be available highlighting each of the presentations. To request a copy, contact Monti Golla, administrator of the GLCI at $979-268-0980$, or by email at grazinglands@cox-internet.com.

Resource Roundup is compiled by Kindra Gordon. Contributionswelcome at kindras@gordonresources.com or call (605)722-7699.

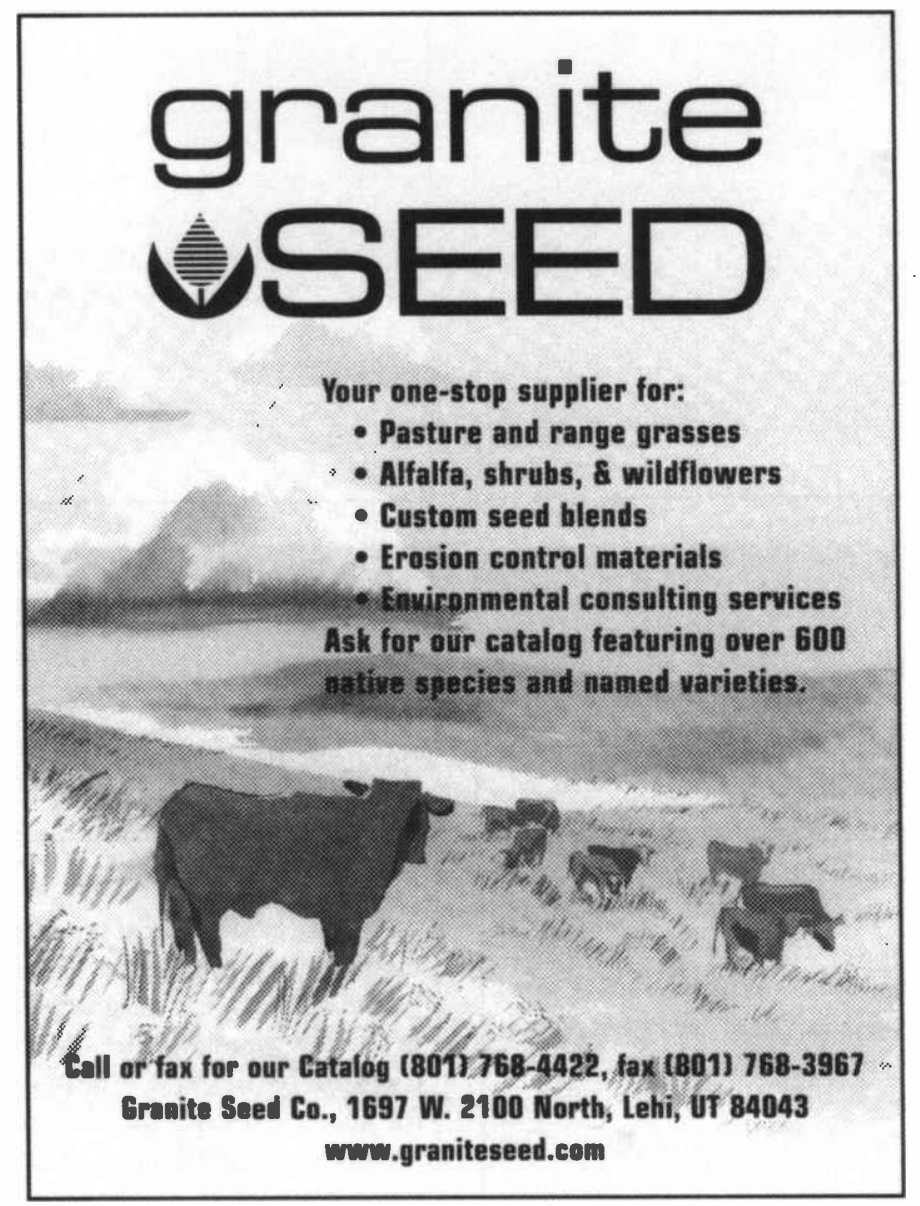




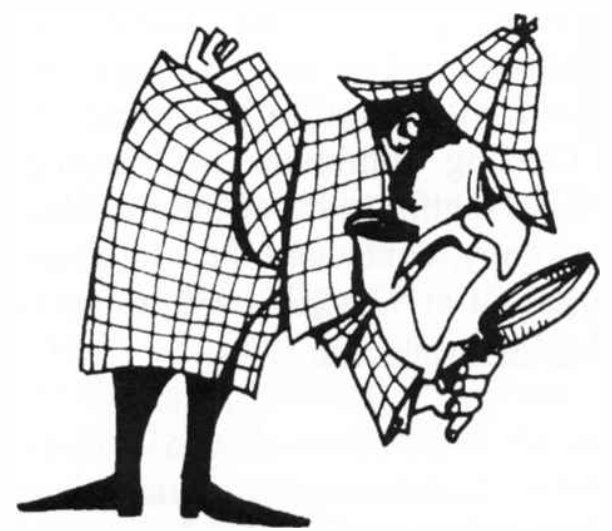

\section{Vegetation, Phosphorus, And Dust Gradients Downwind From A Cattle Feedyard}

Richard W. Todd, Wenxuan Quo, Bobby A. Stewart, and Clay Robinson

Shortgrass pasture downwind from a cattle feedyard near Bushland, Texas changed from native perennial grasses to annual grasses and forbs nearest the feedyard after operation began 1970. Vegetation, soil P and dust deposition were quantified with distance downwind from the feedyard to determine the spatial extent of changes. Little barley, kochia, soil P and dust were greatest nearest the feedyard and decreased with distance downwind, while buffalograss and blue grama were much reduced nearest the feedyard and increased with distance downwind. Though dramatic near the feedyard, impacts on vegetation and soil $P$ were negligible at more than $500 \mathrm{~m}$ downwind.

\section{The Influence Of Land Use On Desertification Processes}

Marisela Pando-Moreno, Enrique Juardo, Mario Manzano, and Eduardo Estrada

Land use in northeast Mexico is characterized by extensive land clearing, poor agricultural practices, and overgrazing. Potential early desertification was evaluated by measuring the physical, chemical and biological soil conditions at 31 sites over 3 to 6 years. There were significant increases in soil bulk density from 1996 to 1999 and significant decreases in organic matter from 1990 to 1993 on rangelands, while induced grassland and agricultural sites did not differ through time. The changes for induced rangelands and agricultural sites were not significant, but were lower than in a protected site which may indicate soil degradation occurrence prior to sampling.

\section{Sneek A Peek} The Journal Of Range Management

\section{Clinical Signs In Cattle Grazing High Molybdenum Forage}

Forage high in molybdenum may affect agricultural uses of reclaimed mine tailings areas. A study in British Columbia evaluated $\mathrm{Mo}$ and $\mathrm{Cu}$ levels in forage and the clinical signs of poisoning in cattle to determine if cattle could graze the forage without ill effects. Clinical signs of lameness were documented in less than half of the cows grazing forage with extremely high levels of Mo (> $100 \mathrm{ppm}$ ). Decreasing the duration of exposure to high Mo forage and supplementation with alternative forms of dietary $\mathrm{Cu}$ may alleviate clinical disorders and ensure cattle grazing without ill effects.

\section{Feral Horse Seasonal Habitat Use On A Coastal Barrier Spit}

Richard D. Rheinhardt and Martha Craig Rheinhardt

Management of feral horse populations grazing on barrier islands and spits requires information on habitat preferences. Aerial surveys and on-ground observations were used to determine seasonal habitat preferences of horses on a North Carolina barrier spit. The horses showed a season preference for specific forage species and habitat types. Seasonal habitat preferences should be considered when managing for ecosystem sustainability on barrier islands. 


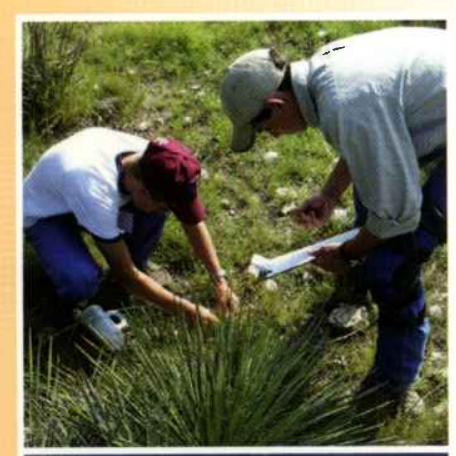

\section{Periodicals}

The Journal of Range

Management (JRM) continues

to serve as an excellent resource

in the field of rangeland

management and science

research. Over 2,800 individuals, libraries, universities, government agencies and other institutions subscribed to $J R M$ in 2003.

Rangelands celebrated its $25^{\text {th }}$ Anniversary in 2003 with special

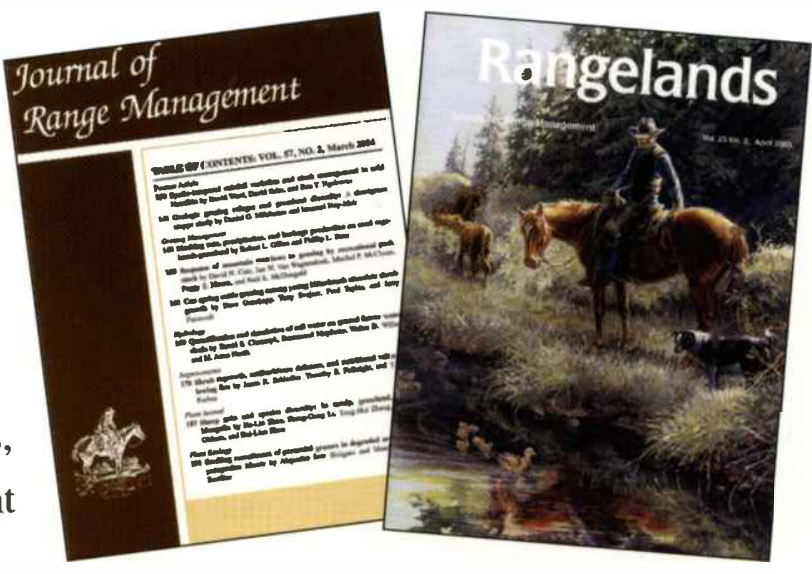

retrospective articles covering the growth and maturity of both the Society and the profession.

\section{Annual Meeting}

SRM's annual meeting in Casper, WY, with the theme "Rangelands: Diversity Through Time",

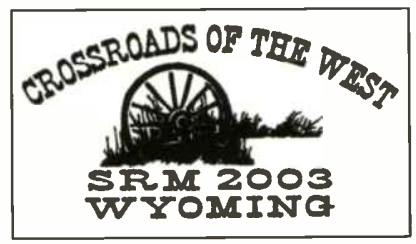
as rangeland birds, carbon sequestration and shortgrass prairie ecosystems. The trade show, high was a huge success. Over 1,600 people from all over the U.S. attended school and college student events, the educational event. The days were filled with dozens of symposia and technical sessions on topics as diverse along with the technical tours and special activities ensured all attendees had a great time while learning and networking.

\section{Certification}

SRM's Certified Professional in Rangeland Management (CPRM) program continued to grow and at the conclusion of 2003 , there were almost 600 professionals that held the prestigious certification. SRM's Certified Range Management Consultant

(CRMC) program also made positive strides. Both programs strive to ensure quality technical services are provided on rangelands and serve as a means of improving the standards of professional expertise used in managing public and private rangelands. 


\section{The Society for Range Management}
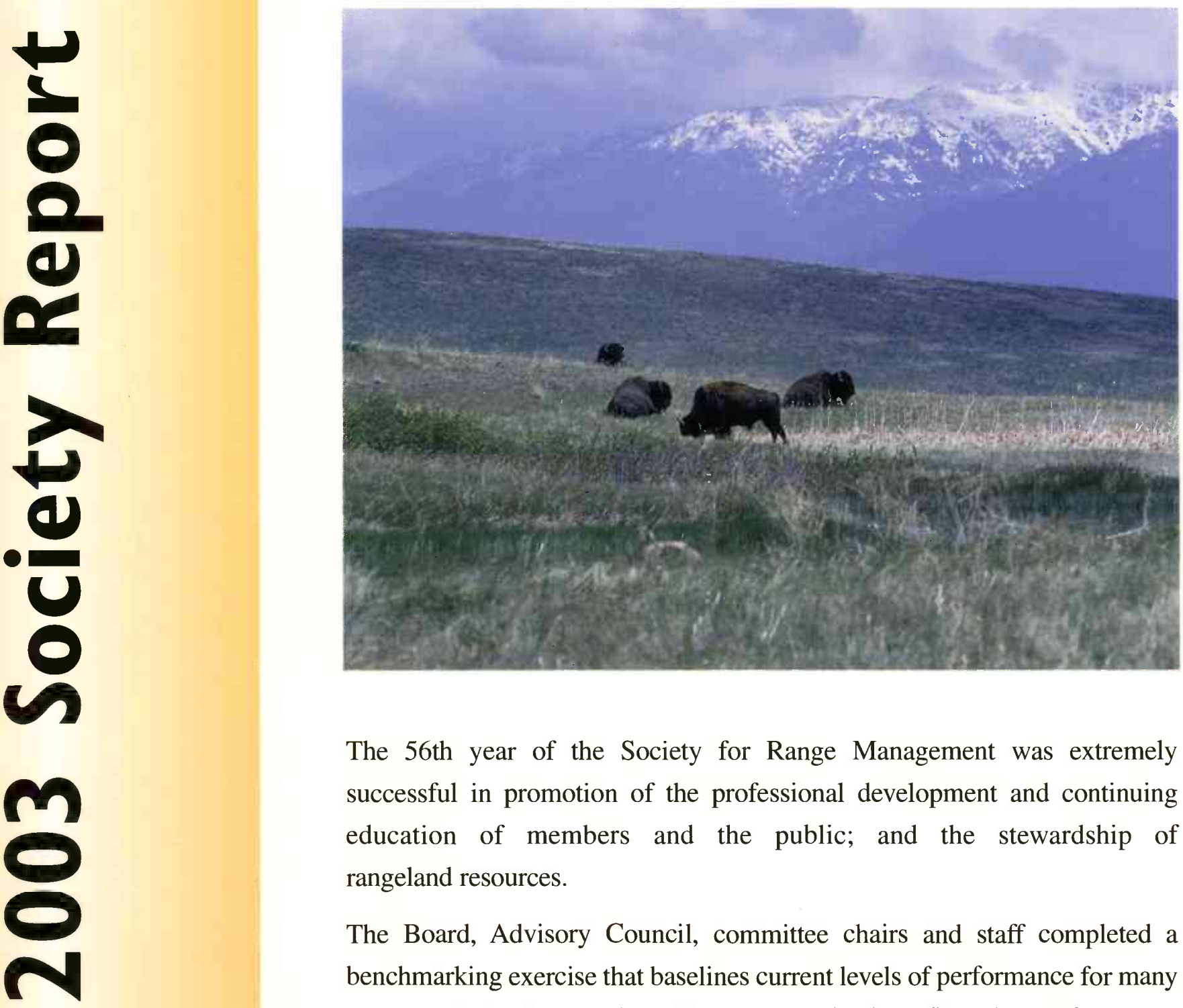

The 56th year of the Society for Range Management was extremely successful in promotion of the professional development and continuing education of members and the public; and the stewardship of rangeland resources.

The Board, Advisory Council, committee chairs and staff completed a benchmarking exercise that baselines current levels of performance for many aspects of the Society including communication, financial performance, staff, leadership and program accomplishment. Annual participation in this effort provides even more information for future planning. The Board of Directors followed this with a full day of strategic thinking that resulted in a strategic initiative list with 37 priority tasks.

Membership was a special focus area for SRM and the Society is happy to report that membership grew by $8 \%$ in 2003, starting 2004 with 3,787 members. Over 500 new members were recruited and membership renewals were up. 


\section{Sections}

Much of SRM's success and achievements in 2003 can be attributed to the Society's sections. These sections sponsor high school activities such as Range Camps where hundreds of youth get hands-on experience with rangeland conservation and management activities. They also work closely with other youth programs such as

\section{Education and Information}

In order to help meet SRM's education and information goals, the Society produced our first issue paper titled "Biodiversity of Rangelands" and four new rangeland resource flyers covering state, national and worldwide rangelands. The "Career in Rangeland Management" brochure was also updated.

SRM began delivering "Range Flash", a special blast email containing timecritical rangelands and membership topics that could not wait for the monthly newsletter. Additionally, SRM started delivering the monthly
4-H and FFA and many provide college scholarships. The sections sponsor environmental stewardship and excellence in range management awards programs for professionals and landowners. Through these activities, and many technical symposia, the SRM sections are the key outreach tool of the Society.

e-newsletter "Member Resource News" by email to approximately 3,000 members saving the Society thousands of dollars.

A major focus in 2003 was the SRM website - www.rangelands.org. Considerable time and effort went into making this site more valuable as a portal for rangelands information both by increasing the technical content on the site and providing over 130 rangelands links. Additional enhancements also make the site much more useful to members serving as an online directory and membership resource.
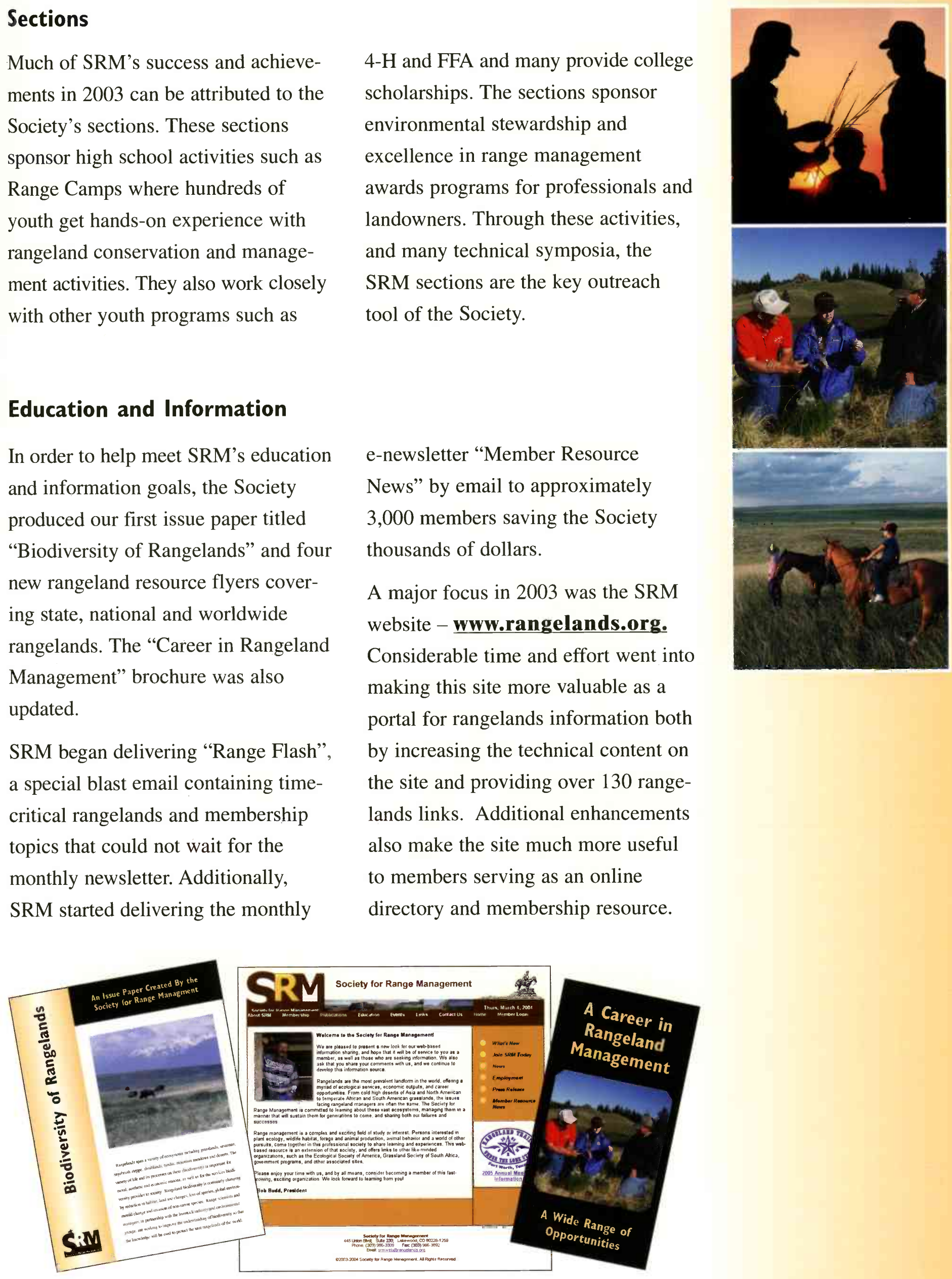


\section{Government Relations}

As usual, government relations was a primary focus for SRM in 2003 with an emphasis placed on SRM's working relationships with the major U.S. federal agencies. With the SRM satellite office in Washington D.C., the Society was able to stay on top of critical issues that affected SRM's members and the rangelands profession. Additionally, SRM's Board of Directors spent three days in Washington D.C. visiting with key appointed officials and partner organizations. A major accomplishment for SRM was that the Bureau of Land Management added a liaison position with SRM that, with the existing Natural Resources Conservation Program position, brings the Society's technical services staff to two full-time range specialists.

\section{International Activities}

SRM played an integral role in international activities in 2003 . The Society helped coordinate U.S. participation in the International Rangelands Congress in Durban, South Africa and many SRM members and government agencies attended this event, held in a different country every five years. An SRM representative was also sent to the Argentina Rangelands Congress and to an international policy workshop on sustainable grassland and livestock in China.
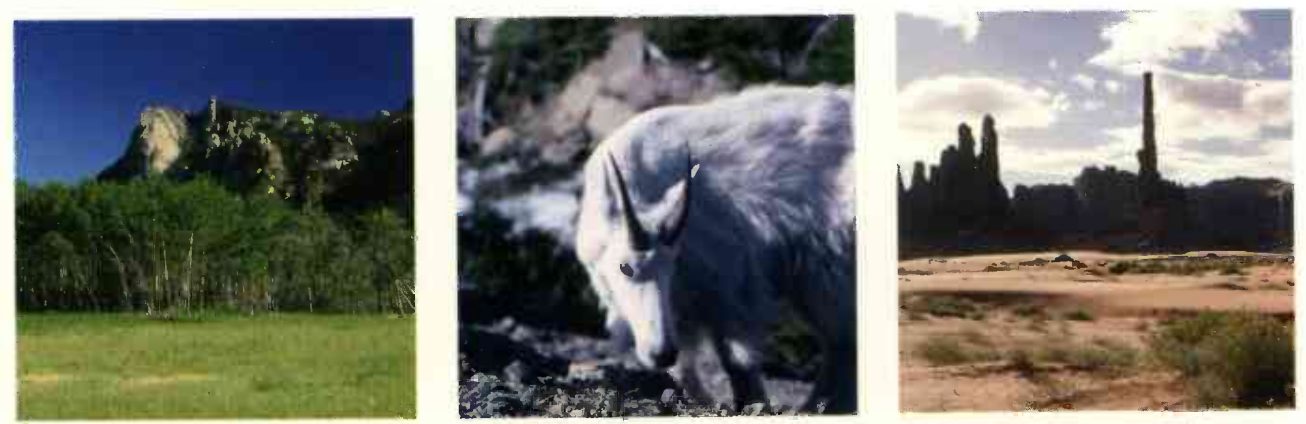

\section{For More Information:}

The Society for Range Management (SRM) is a professional and scientific organization whose members are concerned with studying, conserving, managing and sustaining the varied resources of rangelands. We invite you to contact the Society at:

\section{Society for Range Management \\ 445 Union Blvd, Suite 230 \\ Lakewood, CO 80228 \\ 303-986-3309}

www.rangelands.org • info@rangelands.org 


\section{Landowner Willingness To Participate In A Texas Brush Reduction Program}

\author{
Urs P. Kreuter, Mark R. Tays, and I. Richard Conner
}

Texas primarily consists of privately owned land with brush cover on much of the area that may affect off-site water yield. A survey questionnaire to 720 landowners identified factors that influence their participation in a brush reduction program to increase water yield. Fifty eight of the survey participants responded with $82 \%$ showing a willingness to enroll part of their land in a brush reduction program. It may be preferable to maximize the area enrolled in a brush removal program by targeting larger landowners who are willing to enroll without compensation that exceeds their net cost of enrollment.

\section{Plant Wax Alkanes And Alcohols As Herbivore Diet Composition Markers}

Miguel N. Bugalho, Hugh Dove, Walter Kelman, Jeff Wood, and Robert Mayes

Plant wax alkanes have been used to estimate the species composition of herbivore diets, but for complex diets, longchain fatty alcohols may provide additional markers. Multivariate analyses of n-alkane and long-chain fatty alcohol concentration data from pasture plant species harvested in New South Wales, Australia were used to discriminate plant species groupings. Differentiation among clovers, Lotus spp., $\mathrm{C}_{3}$ and $\mathrm{C}_{4}$ grasses, and the proportion of correctly classified species were better when using n-alkanes and long-chain fatty alcohols together, compared with n-alkanes alone. Long-chain fatty alcohols provided additional discriminatory information that could therefore be used to distinguish species in herbivore diets.

\section{Long-Term Grazing Effects On Genetic Variation In Idaho Fescue}

David Matlaga and Keith Karoly

The effects of cattle grazing on the genetic structure of native grass populations are not known. We investigated the impact of cattle grazing on genetic variation in Idaho fescue in southeastern Oregon using inter-simple sequence repeat DNA markers. Our results differed from past studies that found demographic and physiological differences inside and outside long-term grazing exclosures at our study site. We propose that either the mechanisms that can change neutral genetic variation are not affected by cattle grazing or that effects of grazing on genetic structure were overwhelmed by gene flow between our grazed and ungrazed samples.
Revegetation Of Waste Fly Ash Landfills In A Semiarid Environment

Gary M. Pierzynski, Joshua L. Heitman, Peter Kulakow, Gerard J. Kluitenberg, and James Carlson

Revegetating fly ash disposal sites is challenging in semiarid environments, especially if the soil available for cover has chemical or physical limitations. Mixtures of fly ash, fine sand and cattle manure were used in growth chambers and greenhouses to identify native plant species that would be suitable for plant cover for fly ash landfills in southwest Kansas. Small amounts of fly ash increased the $\mathrm{pH}$ and salinity of the cover sand. Salinity played a major role in plant selection as only the salt tolerant alkali sacaton was able to grow relatively unaffected in mixtures containing fly ash.

\section{Effects Of Distance From Cattle Water Developments On Grassland Birds}

Andrea S. Lueders, Patricia L. Kennedy, and Douglas H. Johnson

Many North American grassland bird populations appear to be declining which may be due to a result of water developments and confining cattle to small pastures. We assessed cattle use, vegetative structure and bird population densities with distance from water on the Little Missouri National Grassland in North Dakota. Cattle use is higher closer to water developments which affected the densities of lark buntings and horned larks. Changes in range managment practices such as increasing water supplies may have an impact on local bird densities.

\section{Leafy Spurge Effects On Patterns Of Plant Species Richness}

Jack L. Butler and Daniel R. Cogan

Information is needed that simultaneously addresses the aggressive effects of leafy spurge on plant species richness at a variety of spatial scales. The impact of leafy spurge on plant species richness within and among a wide variety of vegetation types was investigated in the South Unit of Theodore Roosevelt National Park in southwestern North Dakota. Plot and total species richness was less than species richness within their non-infested counterparts. The overall effects of leafy spurge on richness are complex and may involve patterns of soil moisture, nutrient conditions, and disturbances that influence the abundance and distribution of all alien plants. 


\section{Patch Burning Effects On Grazing Distribution}

Lance T. Vermeire, Robert B. Mitchell, Samuel D. Fuhlendorf, and Robert L. Gillen

Burning portions of management units has been discouraged to prevent localized overgrazing, but if grazing distribution is predictable, patch burning could be employed as an effective grazing distribution tool. We determined cattle grazing preference for burned and non-burned sites, examined whether forage utilization was affected by season of burn, determined forb response to patch burning, and described the relationship between forage utilization and distance from burned sites. Grass utilization was $78 \%$ on burned sites compared to $19 \%$ on nonburned sites, regardless of burn season. Utilization decreased predictably with increasing distance from burned patches and forbs increased only within burned patches.

\section{Fertilization With Nitrogen And Potassium On Pastures In Temperate Areas}

Maria Rosa Mosquera-Losada, Antonio GonzalezRodriguez, and Antonio Rigueiro Rodriguez

Fertilizer application can influence pasture production. The effect of $\mathrm{N}$ and $\mathrm{K}$ fertilization on production, botanical composition, and forage mineral composition was evaluated on perennial ryegrass - white clover pastures in northwest Spain. The fertilizer applications increased herbage production but with different effects on botanical composition. Changing fertilization practices will have a definite influence on sward composition and pasture productivity.

\section{Mourning Dove Sightings Densities On Chihuahuan Desert Rangeland}

Jamus Joseph, Jerry L. Holechek, Raul Valdez and Milt Thomas

Rangeland managers on public and private lands need information on mourning dove use of early-seral rangelands to maintain and possibly increase populations. The mourning dove densities on late-, mid-, and early-seral pastures in the Chihuahuan Desert of south Central New Mexico were evaluated for 3 years. Leatherleaf croton, the primary mourning dove food was more abundant on late- and mid-seral pastures than early seral pastures. The mourning doves of the Chihuahuan Desert prefer moderately grazed, mid-seral rangelands over heavily grazed, mid-seral rangelands.

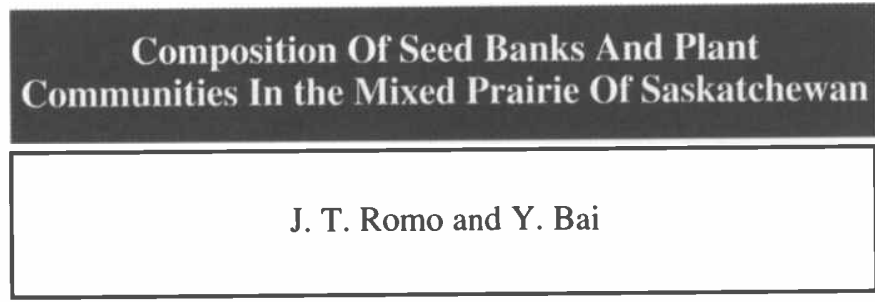

Many range managers have suggested that clubmoss (Selaginella densa Rydb.) negatively alters the abundance of desirable species in seed banks. Composition and diversity of soil seed banks in relation to the clubmoss cover was determined on grazed plant communities. Clubmoss cover was not correlated with species richness, species diversity, density of decreasers, density of increasers, density of invaders, and total seedling densities in the seed banks. We reject the hypothesis that clubmoss negatively affects the composition of seed banks and conclude that managing for seed production by desired species should be a priority in promoting establishment of desired species. 